\title{
Succession and Abundance of Staphylinidae in Cattle Dung
}

\section{in Uberlândia, Brazil}

\section{Jorge Anderson Guimarães, Júlio Mendes ${ }^{+}$}

Departamento de Patologia, Centro de Ciências Biomédicas, Universidade Federal de Uberlândia, Caixa Postal 593, 38400-903 Uberlândia, MG, Brasil

Fimicolous Staphylinidae prey on rearing dipterous in cattle dung, acting as their natural controllers, including pests such as horn fly. To survey the abundance and succession of these coleopterans in cattle dung deposited in pasture, six experiments were conducted from March to October 1995 in Uberlandia, State of Minas Gerais, Brazil. Cattle dung pats were exposed at a pasture for $1 \mathrm{hr}, 8 \mathrm{hr}, 24$ $h r, 2,3,7$ and 10 days and were than taken to laboratory separate from each 025 , for Staphylinidae extraction. A total of 156 dung pats were exposed at pasture, from whe 6225 Staphyinidae were

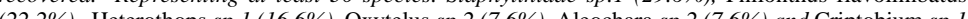
$(4.4 \%)$, Were the most abundant representing $87.8 \%$ from the total. The increased frequency of the majority of these species along the dung exposition time at pasture, indicated tha they wrequency of the on at all the inespecies stores of the dipterous, or eggs and first instar lated of species that lay the dung after its second exposition day at the pasture.

Key words: Staphylinidae succession - cattle dung - horn fly - biocontrol - Brazil

Cattle dung is a microhabitat for an abundant and diverse arthropod fauna (Blume 1985). Diptera, Coleoptera and Hymenoptera are the most abundant arthropods associated with dung pats in pastures (Poorbaugh et al. 1968, Nibaruta 1982, Blume 1985, Cervenka \& Moon 1991, Mendes 1966). A portion of the fauna use dung pats as a breeding pedium while the other part visithento parasite

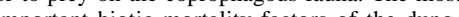
mpolan biotic copre becting tors (Coleoptera), and the paraitoids (Hy(Wi) and the 1974, MaQueen \& Beire 1975, Roth o 1983 . Fay et al 1990). The dung-breeling flies are resposible in part for cattle dung decay. On the other hand, when a the horn fly Haematobia irritans (Linners 1758), the face fly Musca autumnalis (De Geer 1776) and the bush fly Musca vetustissima Walker 1857 (Diptera: Muscide) are important pests of cattle and can cause expensive economic castle (Drummond et al. 1981, Lancaster \& Meisch 1986, Schreiber et al. 1987). The horn fly is a specific blood-sucker of cattle hosts. The fly remains on

Corresponding author. Fax: +55-34-218.2333 Received 24 February 1997 he host's skin piercing constantly and leaves it only to deposit its eggs on fresh cattle droppings in pastures or to pass to another host (MacLintock \& Depner 1954). This fly was recently registered in the North or Brazil (Valerio \& Guimarães 1983). Today it is seen infesting cattle in almost all of the country as well as the ond nerighoning countries

Some arthropods visit or breed in cattle dung concomitantly with immature horn fly. Some of hem are their natural enemies. Many researches the North America, South Africa and Australia have reported the Staphylinidae species diversity in cattle dung and their importance as natural conrollers of horn fly and face fly (Wingo et al. 1974, Harris \& Oliver 1979, Roth et al. 1983, 1988, Hunter et al. 1989, Fay et al. 1990).

Information relating to the period of occurrence and abundance during dung decay are some of the essential basic knowledge about the pest enemies to be used in biological and or integrated control of dung-breeding pests (Wingo et al. 1974, Hunter et al. 1986). With the exception of the researches of Flechtman et al. (1995) and Mendes (1996) the fimicolous Staphylinidae are poorly investigated in Brazil. Therefore, the goal of this work was to survey the abundance and succession of Staphylinidae species during the first 10 days of cattle dung pat decay at a pasture in Uberlândia, State of Minas Gerais, Brazil. 


\section{MATERIALS AND METHODS}

The study area was a Paspalum notatum Flugge pasture at Fazenda do Glória which belongs to the Universidade Federal de Uberlândia (UFU). It is located about $5 \mathrm{~km}$ from Uberlândia, $\left(18^{\circ} 55^{\circ} \mathrm{S}\right.$ $4817 \mathrm{~W}$ ). Dung pats from Holstein dairy cows were collected early in the moning after defecation on a cemented floor at he farm stables. The into pats were placed in plastic pals, mixed up During the month of June July and Aun 1995 . 24 cir and weighting each aut $1 \mathrm{~kg}$, were laid $5 \mathrm{~m}$ apart on the experimental pasture. For March, September and October of the same year the number of the dung pats exposed in the same experiment pasture yard was 28 . After $1 \mathrm{hr}, 8 \mathrm{hr}, 24 \mathrm{hr}, 2,3,7$ and 10 days (in June, July and August $=$ the coole months) 4 dung pats were collected with about 5 $\mathrm{cm}$ of the underlying soil and taken, separate from each other, to the UFU's laboratory of parasitology. Thereafter, two of the four dung pats and its associated soil were transferred to individual Berlese Funnels each of which was equipped with a $60 \mathrm{~W}$ light bulb and these were kept for 5 days or until the funnel's content was conspicuously dry. This technique was used for the extraction of living Staphylinidae beetles from the dung and soil samples described above. The Staphylinidae extraction from the other two pats was hand made using tongs. All the specimens obtained were preserved in $70 \%$ alcohol. The climatic data were obtained at $5^{\circ}$ Meteorological District from Uberlândia, located about $6 \mathrm{~km}$ from the experi-

To test for differences among the Staphylinida abundance and the exposition time of the dung pats at the pasture a one way ANOVA analysis was performed. The means for each main factor an for each species were compared using the multiple comparisons F- test of Tukey. To test for the relationship between the abundance of the species or genera and the respective monthly mean temperatures of the performed experiments Spearman's Correlation Analysis was also performed. All the tas were performed uning the Basic Statsics and Tables a p Nomparnetic Statistics \& DistribuWindows (StatSoft, Inc. 1993).

$$
\text { RESULTS }
$$

The rain precipitation during the months of March, September and October were $239.1 \mathrm{~mm}$ $22.0 \mathrm{~mm}$ and $65.2 \mathrm{~mm}$ and the respective mean temperatures were $23.9^{\circ} \mathrm{C}, 23.3^{\circ} \mathrm{C}$ and $24^{\circ} \mathrm{C}$. The months of June, July and August presented respec- tive climatic data: $3.4 \mathrm{~mm}, 1.6 \mathrm{~mm}$ and $0.0 \mathrm{~mm}$ and $19.1^{\circ} \mathrm{C}, 20.5^{\circ} \mathrm{C}$ and $22.6^{\circ} \mathrm{C}$, being apparty drier and cooler than the other three months. At the experiment's end 156 dung pats had been exposed in the pasture yard area and a total of 6225 adult Staphylinidae belonging to at least $30 \mathrm{spe}-$ cies had been collected (Table I).

TABLE I

Diversity and abundance of Staphylinidae in cattle dung exposed a Fazend do

\section{Species}

\section{Aleochara sp. 1}

Aleochara sp. 2

Aleochara sp. 3

Aleocharinae

Cryptobium sp. 1

Cryptobium sp.2

Cryptobium sp. 3

Dibelonetes hybridus En.

Eulissus chalybaeus Man

Heterothops sp.1

Oxytelus sp.1

ytelus $\mathrm{sp} .2$

Philonthus sp.1
Philonthus sp. 2

Philonthus sp 3

Philonthus sp. 4

P. flavolimbatus Erich.

Staphylinidae sp. 1

Staphylinidae sp.2

Staphylinidae sp.3

Staphylinidae sp. 4

Staphylinidae sp.5

Staphylinidae sp.6

Staphylinidae sp.7

Staphylinidae sp. 8

Staphylinidae sp.9

idae sp. 10

Vatesus sp.

\begin{tabular}{rr} 
Total & $(\%)$ \\
51 & 0.8 \\
470 & 7.6 \\
52 & 0.8 \\
131 & 2.1 \\
273 & 4.4 \\
1 & 0.0 \\
11 & 0.2 \\
7 & 0.1 \\
14 & 0.2 \\
7 & 0.1 \\
1034 & 16.6 \\
20 & 0.3 \\
474 & 7.6 \\
120 & 1.9 \\
35 & 0.6 \\
23 & 0.4 \\
14 & 0.2 \\
76 & 1.2 \\
1382 & 22.2 \\
1841 & 29.6 \\
7 & 0.1 \\
25 & 0.4 \\
3 & 0.1 \\
9 & 0.1 \\
4 & 0.1 \\
2 & 0.0 \\
8 & 0.1 \\
125 & 2.0 \\
3 & 0.1 \\
3 & 0.1 \\
\hline 225 & 100 \\
\hline
\end{tabular}

Staphylinidae sp.1, Philonthus flavolimbatus, Heterothops sp.1, Oxytelus sp.2, Aleochara $\mathrm{sp} .2$ other species by their abundance, representing $87.8 \%$ of the total (Table I). Nevertheless, the ring tive frequency of these groups changed between experiments and with dung age (Table I, Figs 1, increased abundance along the dung exposition time at the pasture The abundance peak occurred in the third day of the dung pats and beyond $(\mathrm{F}=$ 17.64; $p<0.001$ ) (Figs 1, 2). The exception was the Oxytelus sp. 1 in the warmer months, for which the peak of abundance was recorded in the second and third days of the dung exposition. The major-

ty of the most abundant species showed considerable inverse correlation with the monthly mean emperature $(-0.48<\mathrm{r}<-0.3 ; \mathrm{p}<0.001)$. The . ceeding ten days of the data from the time exexceptions were Oxytelus sp. 1 which did not show correlation with temperature and Aleochara sp 2 that presented direct correlationed with this abiotic factor $(r=0.38 ; \mathrm{p}<0.001)$

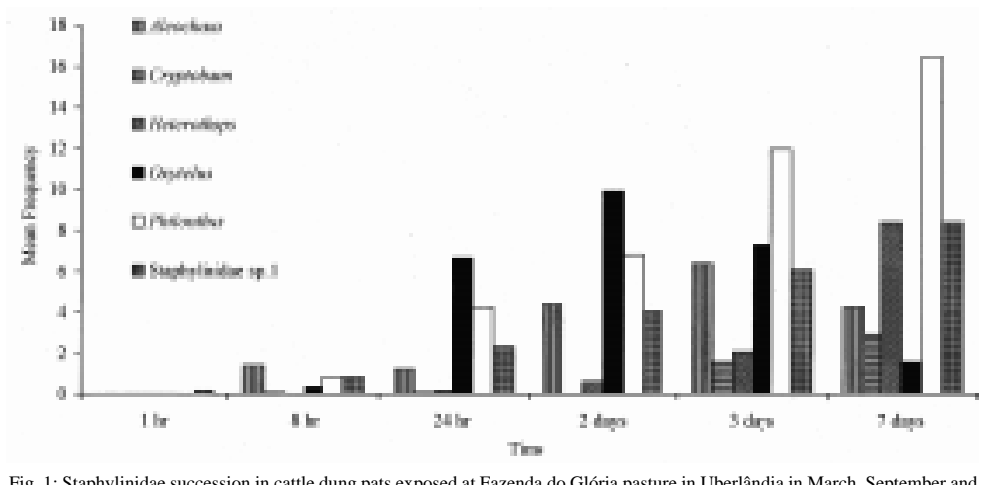

Fig. 1: Staphylinidae succession in cattle dung pats exposed at Fazenda do Glória pasture
October 1995. Showed values are mean frequency by dung pat in each exposition time.

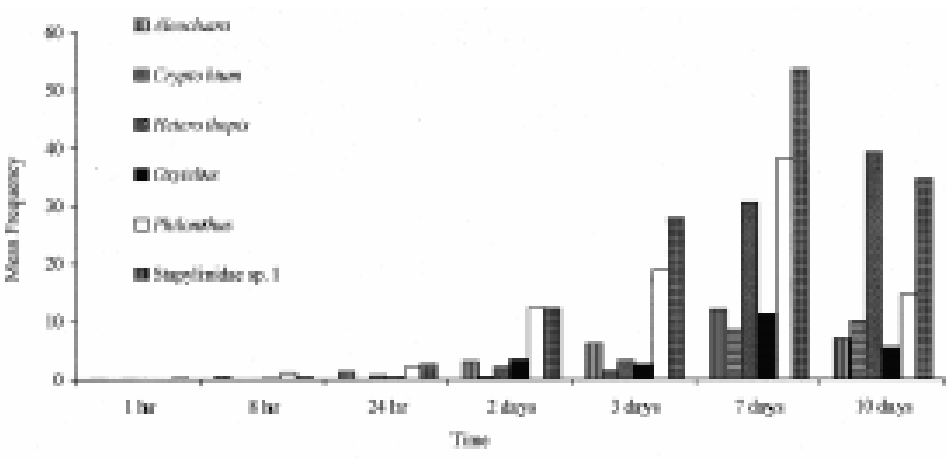


TABLE II

Monthly abundance of Staphylinidae in cattle dung exposed at Fazenda do Glória's pasture in Uberlândia, MG,

\begin{tabular}{|c|c|c|c|c|c|c|c|}
\hline Month & March & June & July & August & September & October & Total \\
\hline leochara sp.2 & 8 & 71 & 104 & 138 & 102 & 47 & 470 \\
\hline Cryptobium sp.1 & 1 & 78 & 37 & 117 & 38 & 2 & 273 \\
\hline Heterothops sp. 1 & 50 & 457 & 333 & 129 & 56 & 9 & 1034 \\
\hline Dxytelus sp.1 & 232 & 188 & 8 & 7 & 15 & 24 & 474 \\
\hline flavolimbatus & 47 & 134 & 274 & 524 & 325 & 78 & 1382 \\
\hline taphylinidae sp.1 & 72 & 1034 & 253 & 291 & 125 & 66 & 1841 \\
\hline ther & 96 & 158 & 127 & 182 & 106 & 82 & 751 \\
\hline otal & 506 & 2120 & 1136 & 1388 & 767 & 308 & 6225 \\
\hline
\end{tabular}

\section{DISCUSSION}

It was expected that the species would be most abundant in the warm months because of the great abundance of prey in the dung in this period (Laurence 1955, MacQueen \& Beirne 1975, Nibaruta 1982, Doube 1986). In spite of the hight Staphylinidae abundance occurring in cool and the dry months, it is important to point out that the data are not sufficient for good inferences about their seasonallity, his will possibly be clarified with an increase in the numer of expentments and a matic changes did not apper to interfere signifcally with a ring at the dung pats (Figs 1,2). The arival of at the dung pats (Frgs 1, 2). The arival of and Staphylinidne sp. 1 arival at the dung pat withi the first $24 \mathrm{hr}$ after its exposition is indicative of their predatory tendency upon dipterous eggs and first instar larvae. On the other hand, the observed increase of the frequency could be due to the possible predation on other larval stages, on pupae and or on eggs and first instar larvae of some Dipter which layed eggs on the dung after the 2nd exposition day. The Staphylinidae access to such larvae and pupae would be enhanced by the dung tunnels previously made by larval Diptera and mature Scarabaeidae (MacQueen \& Beirne 1975).

The arrival of Oxytelus spp. at the dung pad in the first $24 \mathrm{hr}$ of exposition probably indicates tha it aimed to use it as food (Hanski 1987). While the Oxytelus spp. descending curve, between the thir and seventh dung exposition days, could be due to the case of inadequacy of dung as food for such beetles. In the Aleochara spp. case, the increasing frequency would be related to predation along the first days and include egglaying in the later ones, since they are parasitoids when immature. The $P$. flavolimbatus frequency in two days old dung, were mostly below five individuals as pointed out by Harris and Oliver (1979), which responds to a significant reduction in $H$. irritans emergence. Nevertheless, there are many other species which are considered $H$. irritans natural enemies, as the cited above, occurr concomitantly with susceptible $H$.

As in other regions, the Staphylinidae seem to be important natural controllers of Diptera in cattle dung in Brazil. The next step (apart from obtain more data about their seasonallity) would be to estimate predation efficiency data of the most abundant species on $H$. irritans. This study highlight Aleochara sp.2, Cryptobium sp.1, Heterothop sp.1, P. flavolimbatus and Staphylinidae sp.1 for such testing, corroborating Mendes' (1996) observations in the State of São Paulo.

\section{CKNOWLEDGMENTS}

To Drs Cecília Lomônaco and Uriel Franco Roch for the revision of the manuscript.

\section{REFERENCES}

Blume RR 1985. A Checklist, distributional record, and annotated bibliography of the insects associated with Mexico. Southwest Entomol 9: 1-55.

Campano S, Avalos P 1994. Presencia de Haematobia irritans (Diptera: Muscidae) en ganado bovino d Che. Parastol al Dia 18: 59-61.

Pes. Soc 64: 131-143.

Davis ALV, Doube BM, McLennan PD 1988. Habita associations and seasonal abundance of coprophilous coleoptera (Staphylinidae, Hidrophilidae and
Histeridae) in the Hluhluwe Region of South Afirritans immature stages in the dung.
Australia: The potential of the Southern African dung
fauna, p. 16-34. In RS Patterson \& DA Rutz (eds) Biological Control of Muscoid Flies, Miscell. Publications of Ent Soc Am 61, Hyattsville, MD. Doube BM, MacQueen A, Fay HAC 1988. Effects of dung fauna on survival and size of buffalo flies (Haematobia spp.) breeding in the field in South

Drumm and Aula. JAppl Ecol 25. $523-536$. Estim ted losses of livestock to pests, p. 111-127. In D Pimentel, Handbook of Pest Management in Agriculture, Vol 1, CRC Press, Inc Boca Raton, Fl.

Fay HAC, MacQueen A, Doube BM 1990 Impact of fauna on mortality and size of Haematobia spp. (Diptera; Muscidae) in natural dung pats in Austra-
lia and South Africa. Bull Entomol Res 80: 385-392.

lia and South Africa. Bull Entomol Res 80: 385-392.
Flechtmann CAH, Rodrigues SR, Araújo SD, Wenzel RL 1995. Levantamento de insetos fimícolos em Ilha
Solteira, São Paulo, Brasil Rev bras Ent 39: 115-120 Hanski I 1987. Nutritional ecology of dung- and carrion-feeding insects, p. 837-883. In F Slaniki Jr \& JG Rodrigues (eds), Nutritional Ecology of Insects, Mites, Spiders and Relateds Invertebrates, John Wiley \& Sons, Inc., New York.

ris RL, Oliver LM 1979. Predation of Philonth Environ Entomol 8. Hunter JS, Bay

DE, Finsher GT 1986. A survey of Staphylinidae associated with cattle droppings in 88

Hunter JS, Bay DE, Finsher GT 1989. Laboratory and field observations on the life history and habitats of Philonthus cruentatus and Philonthus fla

ancaster JL, Meisch MV 1986. Haematobia irritans Livestock and Poultry Production, John Wiley \& Sons, Inc., New York.

Laurence BR 1955. The larval inhabitants of cow pats. $J$ Anim Ecol 23: 234-260.
MacQueen A, Beirne B 1975. Influence of other insects on production of horn fly, Haematobia irritans (Diptera; Muscidae), from cattle dung in South-Cen-
tral British Columbia. Can Entomol 107: 1255-1264.

McLintock J, Depner KR 1954. A review of life-history and habits of the horn fly, Siphona irritans (L) (Diptera, Muscidae). The Can Enomol 86. 20-32. Mendes J 1996 Artropodofauna Associada a Fezes dos Estégios Imaturos de Haematobia irritans ( $L$ ) (Diptera: Muscidae) na Região de São Carlos, SP. Doctoral Thesis, Universidade Estadual de Campinas, SP, I-VIII + 116 pp.

Nibaruta G 1982. Etude écologique des diptéres associés aux excréments de la vache domestique em milieu temperé. Rev Ecol Biol Sol 19. 203-223.

JH, Anderson JR, Burguer JF 1968. The insects inhabitants of undisturbed cattle droppings in

Roth JP, Finscher GT, Summerlin JW 1983. Competition and predation as mortality factors of the hor fly, Haematobia irritans (L) (Diptera; Muscidae), in a central Texas pasture habitat. Environ Entomol 12. 106-109.

activity Haematobia irritans exigua, in Central Queesland Southwest Entomol 13: 119-124.

Schreiber ET, Campbell JB, Boxler DJ, Petersen JJ 1987. Comparison of beetles collected from the dung of cattle untrealed and treated with fenvalerate ear tags and pastured on two range types western Nebraska.

Valério JR, Guimarães JH 1983. Sobre a ocorrência de Muscidae), no Brasil. Rev Bras Zool 1: $417-418$. Wingo CW, Thomas GD, Clark GN, Morgan CE 1974. Succession and abundance of insects in pasture manure: relationship to face fly survival. Ann Entomol Soc Am 67: 386-390 
132 Succession and Abundance of Staphylinidae • JA Guimarães, J Mendes 